\title{
EFFECT OF SENSORINEURAL HEARING LOSS ON THE TIME-COMPRESSED SPEECH TEST
}

\section{Franz Zenker Castro ${ }^{1}$, Ana Belen Carballo Gonzalez², Maria del Carmen Rodriguez Jimenez ${ }^{3}$, Maria Isabel Olleta Lascarro4, Silvia Marro Cosials ${ }^{5}$, Jose Juan Barajas de Prat ${ }^{3}$}

${ }^{1}$ Clinica Barajas, Santa Cruz de Tenerife, Spain

${ }^{2}$ Fundacion Canaria Dr. Barajas para la Prevencion e Investigacion de la Sordera, Santa Cruz de Tenerife, Spain

${ }^{3}$ Universidad de La Laguna, Santa Cruz de Tenerife, Spain

${ }^{4}$ Centro de Logopedia y Audiologia Isabel Olleta, Logroño, Spain

${ }^{5}$ CREDA Jordi Perello, Sabadell, Barcelona, Spain

Corresponding author: Franz Zenker Castro, Clinica Barajas, Santa Cruz de Tenerife, Spain, e-mail: zenker@clinicabarajas.com

\begin{abstract}
Background: The comprehension of spoken language is based on the analysis of complex acoustic signals by the central auditory system. Cognitive declines and deficits in speech understanding are seen in aged individuals and also in the hearing impaired. The Time-Compressed Speech Test is a low redundancy central auditory processing test that evaluates the closure ability to recognise degraded acoustic speech, words, or sentences.

Material and Methods: In this work, we evaluated the difficulties in understanding compressed speech. Volunteer patients, both with normal hearing and with hearing loss, took part in the experiments. Also a group of hearing aid users were included. The stimuli consisted of speech words that were either unmodified in duration or time-compressed and presented at the most comfortable level.
\end{abstract}

Results: An inverse relationship was seen between the compression ratio and the capacity to identify correctly the words presented. Compressed words were worse perceived by hearing-aid users than by patients with flat audiograms and with a high-frequency hearing loss.

Conclusions: In patients with a flat audiogram, a deficit in the mechanism of temporal resolution exists. Furthermore, hearing aids facilitate the audibility of sound even though they do not act efficiently with speech at high ratios of presentation.

\section{ЭФФЕКТ СЕНСОНЕВРАЛЬНОЙ ТУГОУХОСТИ ПРИ РЕЧЕВОМ ТЕСТЕ С ИСПОЛЬЗОВАНИЕМ ВРЕМЕННОЙ КОМПРЕССИИ}

\section{Резюме}

Введение: Понимание речи основывается на анализе комплексных акустических сигналов центральной слуховой системой. Когнитивные расстройства и недостатки в понимании речи наблюдаются у пожилых людей, а так же у людей с нарушениями слуха. Речевой тест при использовании временной компрессии - это тест на недостаток центральной слуховой обработки, который оценивает способность распознавания ухудшенной акустической речи, слов и предложений.

\begin{abstract}
Материал и методы: В данной работе мы провели оценку трудностей понимания речи в компрессии. Пациенты с нормальным слухом и с нарушениями слуха добровольно приняли участие в экспериментах. Так же была включена группа людей, носящих слуховые аппараты. Стимулом являлись слова речи, которые с одной стороны были не подданы изменениям длины, а с другой были слова, сжатые во времени. Все слова были представлены на наиболее комфортной громкости.
\end{abstract}

Результаты: Была отмечена обратная связь между степенью компрессии и способностью правильного определения представленных слов. Сжатые слова хуже были приняты пациентами со слуховыми аппаратами, чем пациентами с аудиограммами в пределах нормы и нарушением слуха на высоких частотах.

Заключение: Пациенты с аудиограммами в пределах нормы имеют дефицит механизмов временного разрешения. Более того слуховые аппараты облегчают слышимость звука, не смотря на то, что они не достигают максимальной эффективности в случае речи на высоких частотах. 


\section{LA EVALUACIÓN DE PERDIDA DE AUDICIÓN NEUROSENSORIAL MEDIANTE EL TEST DE HABLA COMPRIMIDA}

\section{Extracto}

Introducción: La comprensión de lenguaje hablado está basada en el análisis de señales acústicas por el procesamiento auditivo central. Las decadencias cognoscitivas y los déficits en la capacidad para entender el discurso son vistos en caso de las personas de edad y también con hipoacusia. El Test de Habla Comprimida es una prueba que disminuye la redundancia del procesamiento auditivo central y valora la capacidad de reconocimiento del discurso acústico degradado, palabras, u oraciones.

Material y Métodos: En este estudio se evaluaron las capacidades de identificación del habla comprimida. En los experimentos participaron los pacientes normoyentes y pacientes hipoacúsicos. Un grupo de pacientes con prótesis auditivas fueron también incluidos. Los estímulos presentaron las palabras no modificadas en la duración y los fonéticamente comprimidas presentados a un nivel más comfortable.

Resultados: Hay una relación inversa entre los ratios de compresión y la inteligibilidad verbal. Las palabras comprimidas fueron peor identificadas por los sujetos con prótesis auditivas respecto a los sujetos con audición normal e hipoacúsicos con pérdidas auditivas en las frecuencias agudas.

Conclusiones: En pacientes con audición normal existe un díficit en el mecanismo de la resolución temporal. Por otro lado, las ayudas auditivas sí bien facilitan la audibilidad de los sonidos no actúan eficientemente sobre el procesamiento de habla presentada en las frecuencias agudas.

\section{Background}

Central auditory processing (CAP) refers to the efficiency and effectiveness with which the central nervous system (CNS) utilises auditory information [1]. CAP disorders refer to difficulties in the perceptual processing of auditory information in the CNS, as demonstrated by poor performance in auditory mechanisms, such as sound localisation, auditory discrimination, auditory pattern recognition, temporal aspects of audition, and auditory performance with degraded acoustic signals [2]. Diagnosis of Central auditory processing disorders (CAPD) is established using a battery of approach tests, which may include both behavioural and electrophysiological tests [3]. The Time Compressed Speech Test (CST) is a monaural low redundancy test, commonly included in the CAPD battery of tests, similar to the filtered speech test.

Acoustic redundancy in real-world listening situations is reduced, as compared with quiet, undistorted situations. In describing auditory behaviour, we need clinical tests that can reflect the complexity of these listening situations. Temporal alteration of speech stimuli in the form of time compression is a way to reduce the extrinsic temporal redundancy of the speech signal [4]. Time compression alters the rate of presentation of speech without changes in pitch, articulatory properties, or prosody of the original speech material [5].

Time compression is typically accomplished by regularly discarding portions of the speech signal. The rate of speech may be increased either by having the speaker alter the rate of articulation or by changing the rate of digital playback with respect to the rate of the recording [6]. The most frequent time compression technique used nowadays consists of removing portions of the speech waveform in order to shorten the speech sample [7]. This procedure does not alter the power spectrum of the speech.

The temporal composition of the resulting verbal material depends on the compression rate finally applied (i.e., the extent to which the signal is shortened). This percentage is the result of how often portions of the signal are discarded and the length of the discarded intervals. Speech that is compressed by $60 \%$ means that $60 \%$ of the signal has been deleted by regularly discarding $60 \%$ of specified intervals.

The effects of temporal alterations on speech perception differ with varying speech materials. It has been shown that comprehension test scores decline more rapidly than word recognition scores when the time-compression rate of speech is increased [8]. Clinically, TCS materials have been used on a variety of patients with neurological deficits [9-11]. A degradation of the speech signal generally has a greater deleterious effect on patients with central neurological deficits than in patients with normal central neurological systems.

In this study, we present preliminary data obtained with the Compressed Speech Test for Spanish-speaking patients in normal-hearing subjects, hearing-loss subjects and hearing-aid users. The test consists of disyllabic words that were time compressed at $0,50,60$, and $70 \%$. We studied the effect of time compression on the capacity to recognise speech on this group of participants.

\section{Material and Methods}

\section{Subjects}

Exactly 73 right-handed subjects (35 males and 38 females) aged from 18 to 78 were evaluated. The sample was divided into 4 groups according to their hearing status. The participants' bilateral four-frequency average (4FA) hearing loss measured across $0.5,1,2$, and $4 \mathrm{kHz}$ ranged from normal to severe (range: $11.7-86.3 \mathrm{~dB} \mathrm{HL}$ ). The auditory thresholds obtained from liminal tonal audiometry in the normal-hearing subjects were less than $30 \mathrm{~dB}$ HL. The group of hearing-impaired subjects was selected according to the following criteria: a) auditory sensitivity greater than $40 \mathrm{~dB} \mathrm{HL}$; b) difference between air and 
Table 1. Mean pure-tone air-conduction thresholds for the three listener groups: normal hearing, flat hearing loss, and high frequency hearing loss. Also shown is the speech reception threshold and maximum speech discrimination score.

\begin{tabular}{|c|c|c|c|c|c|c|c|c|c|c|c|c|}
\hline \multirow{3}{*}{ Listener group } & \multicolumn{4}{|c|}{$\begin{array}{c}\text { Pure Tone Threshold } \\
\text { (dB HL) }\end{array}$} & \multicolumn{4}{|c|}{$\begin{array}{c}\text { Speech Reception Threshold } \\
\text { (dB nHL) }\end{array}$} & \multicolumn{4}{|c|}{$\begin{array}{l}\text { Maximum Speech } \\
\text { Discrimination (\%) }\end{array}$} \\
\hline & \multicolumn{2}{|c|}{ Right } & \multicolumn{2}{|c|}{ Left } & \multicolumn{2}{|c|}{ Right } & \multicolumn{2}{|c|}{ Left } & \multicolumn{2}{|c|}{ Right } & \multicolumn{2}{|c|}{ Left } \\
\hline & Mean & $\pm \mathrm{SD}$ & Mean & \pm SD & Mean & \pm SD & Mean & $\pm \mathrm{SD}$ & Mean & $\pm S D$ & Mean & $\pm \mathrm{SD}$ \\
\hline Normal hearing $(n=26)$ & 25.61 & $(1.95)$ & 28.32 & $(1.82)$ & 25.34 & $(1.02)$ & 27.32 & $(1.25)$ & 98.56 & $(1.78)$ & 99,45 & $(1.64)$ \\
\hline Flat hearing loss $(n=25)$ & 52.28 & $(5.12)$ & 58.63 & $(6.55)$ & 65.10 & $(4.27)$ & 69.25 & $(3.60)$ & 91.15 & $(2.48)$ & 87,78 & $(3.14)$ \\
\hline $\begin{array}{l}\text { High frequency hearing } \\
\text { loss }(n=22)\end{array}$ & 74.52 & $(7.62)$ & 79.84 & $(7.64)$ & 81.67 & $(8.81)$ & 83.33 & (3.33) & 89.33 & $(10.67)$ & 81.33 & $(15.87)$ \\
\hline
\end{tabular}

bone conduction thresholds no greater than $10 \mathrm{~dB} \mathrm{HL} ; \mathrm{c})$ difference between thresholds of the right ear and left ear less than $15 \mathrm{~dB} \mathrm{HL}$; d) maximum speech discrimination (MSD) greater than $80 \%$ in both ears; and e) difference of less than $10 \%$ between the MSD obtained in the right and left ears. The group of hearing-impaired subjects was later subdivided in two categories. One group of participants were those with moderate to severe hearing loss and also were current users of bilateral amplification. The same participants were included in the hearing-loss group and in the hearing-aid group. A fourth category were participants with a high-frequency hearing loss. This was established by the presence of a $15 \mathrm{~dB}$ notch at $4 \mathrm{kHz}$ when comparing the threshold to neighbouring frequencies. Table 1 presents the mean liminal tonal threshold for the 4FA, the SRT (speech reception threshold), and the percentage of MSD of the participants in this study.

\section{Material}

Speech material was obtained from the Speech Discrimination List contained in the Notebook on Spanish Speech Audiometry [12]. Time compression was applied using the Sound Forge V5.0 software (Sonic Foundry, 1997). Compression ratios applied were $0 \%$ for list $4 ; 50 \%$ for list 5 ; $60 \%$ for list 6 , and $70 \%$ for list 8 . The amount of compression was derived from the following formula:

$$
\mathrm{Rc}=\left[\mathrm{I}_{\mathrm{d}} /\left(\mathrm{I}_{\mathrm{d}}+\mathrm{I}_{\mathrm{s}}\right)\right]
$$

$\mathrm{I}_{\mathrm{s}}=$ sampling interval

$\mathrm{I}_{\mathrm{d}}=$ discard interval

Segments of the speech signal were alternatively discarded and retained at constant sampling intervals without regard to the contents of the signal. Table 2 shows the sampling intervals and discarded intervals as a result of the different compression ratios applied to the speech material.

\section{Procedure}

Prior to the CST, and in order to rule out any middle ear conditions and possible retrocochlear injury, all participants underwent otoscopic examination, immittance acoustic measures, stapedial reflexes, and brainstem evoked auditory potentials. Auditory sensitivity was established in
Table 2. Compression ratios, sampling interval, and discard interval for list 4, 5, 6, and 7 obtained from the notebook on Spanish Speech Audiometry [12].

\begin{tabular}{ccc}
\hline $\begin{array}{c}\text { Compression } \\
\text { ratio (\%) }\end{array}$ & $\begin{array}{c}\text { Sampling interval } \\
\text { (ms) }\end{array}$ & $\begin{array}{c}\text { Discard interval } \\
\text { (ms) }\end{array}$ \\
\hline 0 & 0.0 & 0 \\
\hline 50 & 18.0 & 18 \\
\hline 60 & 12.0 & 18 \\
\hline 70 & 7.7 & 18 \\
\hline
\end{tabular}

all the subjects by means of pure-tone audiometry (250$8000 \mathrm{~Hz}$ ) and speech testing including SRT and MSD. The CST scales were presented by means of a compact disc player (Sony, Model D-NE240) and amplified through an audiometer (Grason-Stadler, Model 16) with TDH39 headphones with supraaural cushions. The list of CST was administered at $65 \mathrm{~dB}$ nHL for normal hearing subjects and $35 \mathrm{~dB}$ higher than the SRT in the case of hearing-impaired subjects. For the group of hearing-aid users, the CST lists of words were presented in the free field at the most comfortable level. All word lists and experimental conditions were counterbalanced across subjects. Participants were given 15 practice items before testing. Finally, participants were asked to repeat the words presented to both ears.

\section{Data analysis}

The result obtained was analysed by studying the effect of compression ratio on speech recognition capacity. Means of correct speech recognition by the hearing group were obtained for each subject. The results were expressed as percentages of correct answers. An arcsine transformation [13] was performed for the speech recognition scores before statistical analysis to account for unequal variances that occur with percent correct scores. Auditory status was studied as independent variables between subjects. The design consisted of $4 \times 4$ repeated measures. An analysis of the variance (ANOVA) was used to compare factors. Tukey's DHS test was used for subsequent analysis. The level of statistical significance was set to 0.05 . 


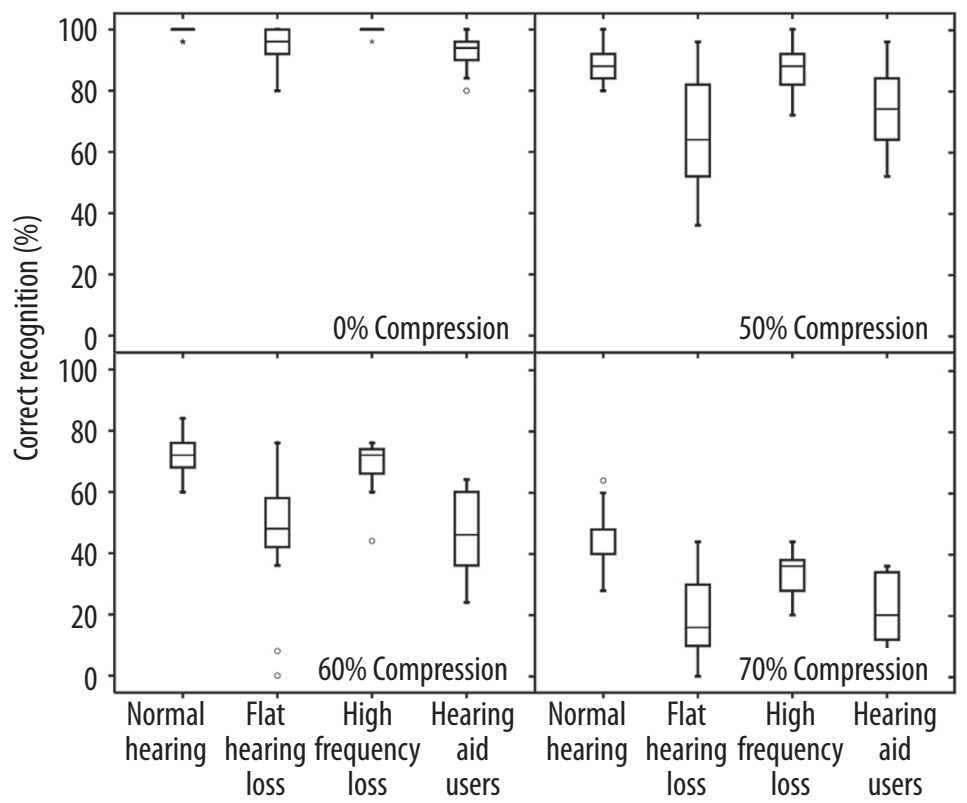

Figure 1 . Box plot of correct recognition scores by hearing group and compression ratio.

\section{Results}

Figure 1 presents, for the different compression ratios applied, descriptive statistics by means of a box and whisker diagram depicting the median interquartile range and total range for percentages of correct word recognition. Better scores were obtained for all subjects with smaller time compression. As compression ratio increased, the percentage of correct recognition decreased. Normal hearing subjects and participants with high frequency loss showed better scores in all conditions than participants with flat hearing loss and hearing-aid users.

Figure 2 shows scores of correct speech recognition as a function of compression ratio and hearing sensitivity. The ANOVA shows a significant principal effect as a function of compression ratio $(F[3,15]=68.254 ; p<0.0001)$ and hearing group $(F[3,15]=68.254 ; p<0.0001)$. The posterior analysis DHS of Tukey shows significant differences on the percentage of correct recognition between normal hearing and hearing loss subjects $(p<0.0001)$ and the hearingaid users group $(p<0.0001)$. Moreover, a significant difference was found between the high-frequency hearing-loss subjects $(p<0.0001)$ and the flat hearing-loss group and hearing-aid users $(p<0.0001)$. No differences were found either between the normal hearing group and the highfrequency hearing-loss group, or between the flat hearingloss group and the hearing-aid users.

\section{Discussion}

The Compressed Speech Test is a monaural low-redundancy test used in the diagnosis of CAPD. This test is a non-invasive procedure used in examining auditory temporal resolution mechanisms. In this study we analysed the verbal recognition score in the CST of a population of normal and hearing-disabled subjects. Recognition abilities were measured as function of the difficulty of the

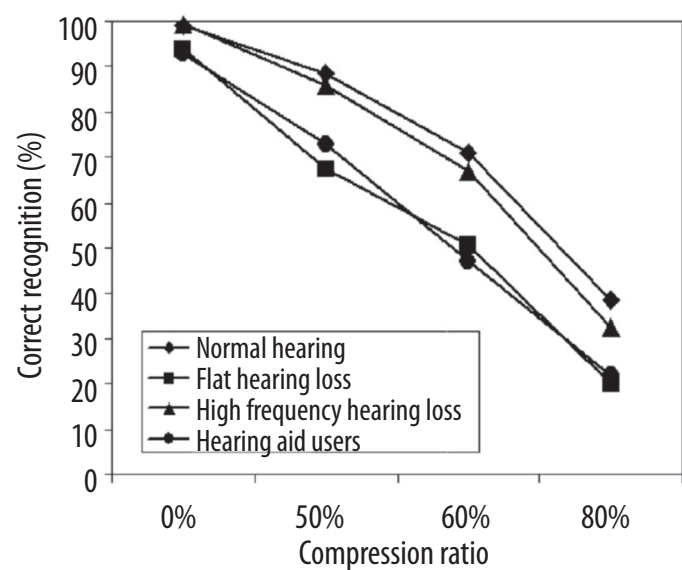

Figure 2. Percentage of correct verbal recognition as a function of compression ratio by hearing group.

test and of hearing status. The results obtained by normal hearing subjects are consistent with previous studies where a decrease in the capacity of correct recognition is systematically observed as the difficulty of the test increases.

In a group of normal subjects, Beasly et al. [4] found that speech recognition capacity significantly decreased for a compression ratio of $60 \%$ and above. Wilson et al. [14] found that for a compression ratio of $65 \%$, speech recognition decreased significantly to $20 \%$ with a $75 \%$ compression ratio. In the present study, normal-hearing subjects had $82 \%$ correct recognition with a compression ratio of $60 \%$ that droped to $33 \%$ with a compression ratio of $70 \%$.

Hearing-aid users showed significantly worse scores than normal-hearing subjects and high-frequency hearing-loss subjects. In general, the scores of the hearing-aid users 
were similar to those with a flat audiogram. Hearing-aids provide audibility of sounds but have poor performance when speech exceeds normal temporal resolution.

\section{Conclusions}

The results from this study can be summarised as follows:

1. The capacity of word compression recognition decreases as the compression ratio increases. This decrease was stronger for hearing-loss subjects than for hearing-aid users.
2. Flat hearing-loss subjects show a defect in the mechanisms of temporal resolution that manifests itself as a poor capacity for discrimination. This defect is not seen in high-frequency hearing-loss patients.

3. Hearing-loss and hearing-aid patients obtained worse results than participants with high-frequency hearing loss and without hearing-aids. Since for both groups the maximum discrimination was over $80 \%$, this result shows a poor capacity to recognise words that worsens with the use of amplification.

\section{References:}

1. ASHA: (Central) Auditory Processing Disorders [Technical Report], 2005; 1-27

2. ASHA: Central Auditory Processing: Current Status of Research and Implications for Clinical Practice. Am J Audiol, 1995; 5: 41-54

3. Dempsey C: Selecting tests of auditory function in children. In: Katz J (ed.), Central Auditory Processing Disorders: Problems of speech, language, and learning. Baltimore: University Park Press, 1983; 203-21

4. Beasley D, Maki J: Time and frequency-altered speech. In: Lass, L. (ed.), Contemporary Issues in Experimental Phonetics. New York: Academic Press, 1976; 419-58

5. Letowski T, Poch N: Understanding of time-compressed speech by older adults: effect of discard interval. J Am Acad Audiol, 1995; 6(6): 433-39

6. Calearo C, Lazzaroni A: Speech intelligibility in relation to the speed of the message. Laryngoscope, 1957; 67: 410-19

7. Fairbanks G, Kodman F: Word intellibility as a function of time compression. J Acoust Soc Am, 1957; 29: 636-41

8. Foulke E, Sticht T: The intelligibility and comprehension of time-compressed speech. In: Foulke E, (ed.) Proceedings of the Louisville Conference on Time-Compressed Speech. Louisville, KY: University of Louisville, 1967; 21-28
9. Kurdziel SA, Noffsinger D, Olsen W: Performance by cortical lesion patients on $40 \%$ and $60 \%$ time-compressed materials, J Am Audiol Soc, 1976; 2: 3-7

10. Rintelmann WF, Lynn GE: Speech stimuli for assessment of central auditory disorders. In: DF Konkle, WF Rintelmann (eds.), Principles of speech audiometry. Baltimore: University Park Press, 1983; 231-83

11. Mueller HG, Beck WG, Sedge RK: Comparison of the efficiency of cortical level speech test. Semin Hear Res, 1987; 1: 186-95

12. Cardenas R, Marrero V: Cuaderno de logoaudiometria (in Spanish) (Notebook on Speech Audiometry). Universidad Nacional de Educacion a Distancia, Madrid, 1994

13. Studebaker GA: A "rationalized" arcsine transform. J Speech Hear Res, 1985; 28: 455-62

14. Wilson RH, Peece JP, Salamon DL et al: Effects of time compression plus reverberation on the intelligibility of Northwestern University auditory test no. 6. J Am Acad Audiol, 1994; 5: 269-77 